\title{
Tetraphyllidean metacestodes of teleosts of the Great Barrier Reef, and the use of in vitro cultivation to identify them
}

\author{
Clinton B. Chambers ${ }^{1}$, Thomas H. Cribb ${ }^{1}$ and Malcolm K. Jones ${ }^{2}$ \\ ${ }^{1}$ Department of Microbiology and Parasitology, The University of Queensland, Brisbane, 4072, Australia; \\ ${ }^{2}$ Centre for Microscopy and Microanalysis, The University of Queensland, Brisbane, 4072, Australia
}

Key words: Cestoda, Tetraphyllidea, diversity, in vitro cultivation

\begin{abstract}
The tetraphyllidean metacestode diversity of 310 teleost fishes, including 87 species from 31 families, was examined from Heron Island, The Great Barrier Reef, Australia. Eleven metacestode 'types' were identified with the use of light microscopy. Host-specificity varied greatly among metacestode types. Incorporation of in vitro cultivation allowed generic identification for some types. Types 1 and 2 belong to Uncibilocularis Southwell, 1925, and have triloculate bothridia and one pair of forked hooks with unequal prongs; Type 3 has quadriloculate bothridia. Hook development was insufficient to determine in which genus, Acanthobothrium van Beneden, 1849 or Calliobothrium van Beneden, 1850, this type may belong. Type 4 has unilocular bothridia with simple edges and belongs to Anthobothrium van Beneden, 1850. Type 5 has multiloculated bothridia which are invaginated within pouches. This type belongs to the Rhinebothriinae although its generic identity cannot be determined. The bothridia of Type 5 everted within 24 hours of in vitro cultivation and revealed the presence of two forms, one having 48 loculi per bothridium, the other 72 per bothridium. In vitro studies provide additional support for existing theories of onchobothriid scolex development.
\end{abstract}

Tetraphyllidean metacestodes have traditionally been difficult to identify due to their relatively featureless scolex morphology, which lacks the diagnostic features of the adult cestodes. These metacestodes have long been known from the intestines of teleost fish and the genus Scolex Mueller, 1788 was proposed to accommodate them with Scolex pleuronectis Mueller, 1788 the type species (Stunkard 1977). Subsequently, other species were described and placed in this genus until Rudolphi (1819), doubting the validity of these species, synonymised them as Scolex polymorphus Rudolphi, 1819. Observations since then have suggested that the above species represent a number of tetraphyllidean species so that the names $S$. pleuronectis and $S$. polymorphus have become collective names encompassing metacestodes that share features common to this order of cestodes (Wardle and McLeod 1952, Caira and Ruhnke 1991, Dick and Choudhury 1995).

Many species of fish on The Great Barrier Reef are known to harbour tetraphyllidean metacestodes (Lester and Sewell 1989) but no real attempt has been made to distinguish them. A number of workers have endeavoured, using in vitro techniques, to induce maturation of the metacestode scolex to more closely represent that of the adult, thus allowing at least partial identification of the species (Hamilton and Byram 1974, Carvajal et al. 1982). With that purpose in mind, in vitro cultivation was used in addition to morphological techniques to identify and quantify the number of species of tetraphyllidean metacestodes found parasitising teleost fishes of Heron Island, The Great Barrier Reef, Australia.

\section{MATERIALS AND METHODS}

Metacestodes were dissected from their hosts with the aid of a dissecting microscope. Specimens for morphological examination were heat-fixed in near boiling $0.85 \%$ saline solution and preserved in 5\% aqueous formalin. Worms were stained in Mayer's haematoxylin, destained in aqueous $0.5 \%$ $\mathrm{HCl}$ and neutralised in $0.5 \%$ ammonia solution. The worms were then dehydrated in a graded series of ethanols and cleared in methyl salicylate. Worms were mounted in Canada balsam and examined with a light microscope. Drawings were made with the aid of a drawing tube. Measurements are given as averages followed by ranges in parentheses, and are in micrometres unless otherwise indicated. Voucher specimens of types were deposited in the Queensland Museum (QM).

Specimens for cultivation were dissected from their host fish, identified (uncultivated vouchers kept), washed in saline, and placed in a $5 \mathrm{~cm}$ diameter Petri dish containing in vitro cultivation solution. This solution was designed to simulate conditions found in the spiral valve of an elasmobranch (Carvajal et al. 1982) and contained (w/v) $1.46 \% \mathrm{NaCl}, 0.03 \%$ $\mathrm{KCl}, 1.8 \% \mathrm{CaCl}_{2}, 0.06 \% \mathrm{MgCl}_{2} \cdot 6 \mathrm{H}_{2} \mathrm{O}, 0.01 \% \mathrm{Na}$-pyruvate, $0.1 \%$ glucose, $1.8 \%$ urea and $0.12 \%$ Tris buffer. The culture medium was sterilised by passing it through a $0.22 \mu \mathrm{m}$ pore filter. Immediately before use $0.2 \%$ of bovine serum, $100 \mathrm{IU}$ of penicillin and $10 \mu \mathrm{g}$ of streptomycin were added. The osmolality of this solution was $790 \mathrm{mosmol}$ and the $\mathrm{pH}$ 7.4.

Most metacestodes were cultivated in an air-conditioned room at the Heron Island Research Station, maintained at approximately $25^{\circ} \mathrm{C}$. The cultivation solution was changed twice daily. Selected metacestodes were removed each day of culture, heat-fixed, preserved and prepared for light microscopy as described above. 
Those metacestodes viewed with a scanning electron microscope (SEM) were heat-fixed in near boiling $0.85 \%$ saline solution and fixed in $5 \%$ aqueous formalin. Metacestodes were then washed in 3 volumes of $0.1 \mathrm{M}$ cacodylate buffer $(\mathrm{pH}$ 7.2) before post-fixing in osmium tetroxide for 45 minutes. The metacestodes were then washed in distilled water and dehydrated with a graded series of ethanols. Metacestodes were washed in three changes of Hexamethyldisalizane (Pro Sci Tech, Australia), allowing the final volume to evaporate completely. The metacestodes were mounted onto stubs, sputter-coated with gold and viewed with a JEOL 6300 SEM at $5-15 \mathrm{kV}$.

\section{RESULTS}

Studies by light microscopy revealed 11 putative metacestode types (Fig. 1) from a broad range of host fish families and species (Table 1) from Heron Island. These types are designated reflecting an expectation that further study may reveal more species than are recognisable by light microscopy. Measurements are summarised in Table 2. Five of the designated types were investigated with in vitro cultivation techniques.

The pre-cultivation morphology of tetraphyllidean metacestode Type 1 comprised a scolex bearing four triloculate bothridia, an apical sucker and a long, slender body (Fig. 2a). A number of morphological changes were induced during in vitro culture, including the development of a septum posterior to the bothridia, dividing the scolex from the body and the development of one pair of forked hooks with unequal prongs between the $1^{\text {st }}$ and $2^{\text {nd }}$ loculi on each bothridium. The outer prong of each hook was the smaller. The apical sucker degenerated, appearing as a poorly muscularised region (Fig. 2b, c).

Metacestode Type 3 had a scolex morphology comprising an apical sucker and four quadriloculate bothridia (Fig. 2d). In vitro cultivation produced a septum posterior to the scolex, separating the scolex from the body within 24 hours (Fig. 2e). Hook development was evident within 48 hours and primordial hooks represented one pair of forked hooks per bothridium, or two pairs of single hooks (Fig. 2e, f).

Type 4 was a small metacestode with simple unilocular bothridia. Within 24 hours of cultivation, noticeable morphological developments were visible. There was a slight elongation of the body and a septum developed posterior to the bothridia, separating the scolex from the body region. The bothridia enlarged slightly, and the apical sucker began to degenerate. Further cultivation for three weeks produced no sign of hook development. In cultivation, the bothridia of Type 4 retained a simple edge and became slightly pedunculate.

Because the bothridia of Type 5 were inverted and contained in a pouch, only the apical sucker was evident externally on the scolex (Fig. 3a). After 24 hours of cultivation the bothridia evaginated. The bothridia were divided into numerous loculi by a single longitudinal septum and several transverse septa (Fig. 3b). After 48 hours, a cephalic peduncle became obvious and a septum separated this from the body. Some degeneration of the apical sucker was evident after 72 hours. Evagination of the bothridia revealed the presence of two distinct forms within this type. One form had 48 loculi per bothridium and the other 74 loculi, indicating the presence of cryptic species within the 'type' designated by light microscopy.

\section{DISCUSSION}

The number of tetraphyllidean metacestodes found in this study reflects a rich fauna of tetraphyllideans in elasmobranchs on The Great Barrier Reef. This is in contrast to the small number (5) of adult tetraphyllidean cestodes described from Heron Island (Lester and Sewell 1989). It is probable that the diverse array of metacestodes recorded here does not do justice to the true diversity occurring on the reef. In this study, only 87 of over 1500 fish species known to occur on The Great Barrier Reef (Russell 1993), representing only $25 \%$ of known reef fish families, were inspected for metacestodes. Examination of the remaining fish families is likely to reveal more metacestode types, although some of the types recorded here might be expected to be recorded in those fish. Further, the teleosts are only one of several recognised groups of intermediate hosts of tetraphyllideans on the reef. Investigation of other host groups, such as bivalves, is likely to reveal additional tetraphyllidean metacestodes. The presence of cryptic species within the types, as evidenced by Type 5, may disguise an even greater diversity than is recognised here. It appears that much further study is required to elucidate tetraphyllidean diversity on The Great Barrier Reef.

Varying degrees of host-specificity were shown among the metacestode types in this study (Table 1). Metacestode Type 3 showed marked host-specificity, infecting only the goby Valenciennea longipinnis (Lay et Bennett). Type 3 was not found in other gobies, such as Amblygobius phalaena (Valenciennes), which occupy the same habitat and share infections of Types 4 and 5 . Type 4 showed little specificity, occurring in many fish families covering a broad ecological range. This type was even found in large pelagic fish, such as Scomberomorus commerson (Lacepède). It is possible that this metacestode is passed vertically through the food chain, from fish to fish, before reaching its definitive hosts. It is also conceivable that this morphological type incorporates cryptic species, each with its own narrower host-specificity. The discovery of cryptic species within Type 5 serves to establish this possibility.

In vitro cultivation was useful in elucidating generic identification for some metacestode 'types'. Tetraphyllidean metacestode Type 1 was identified as an 

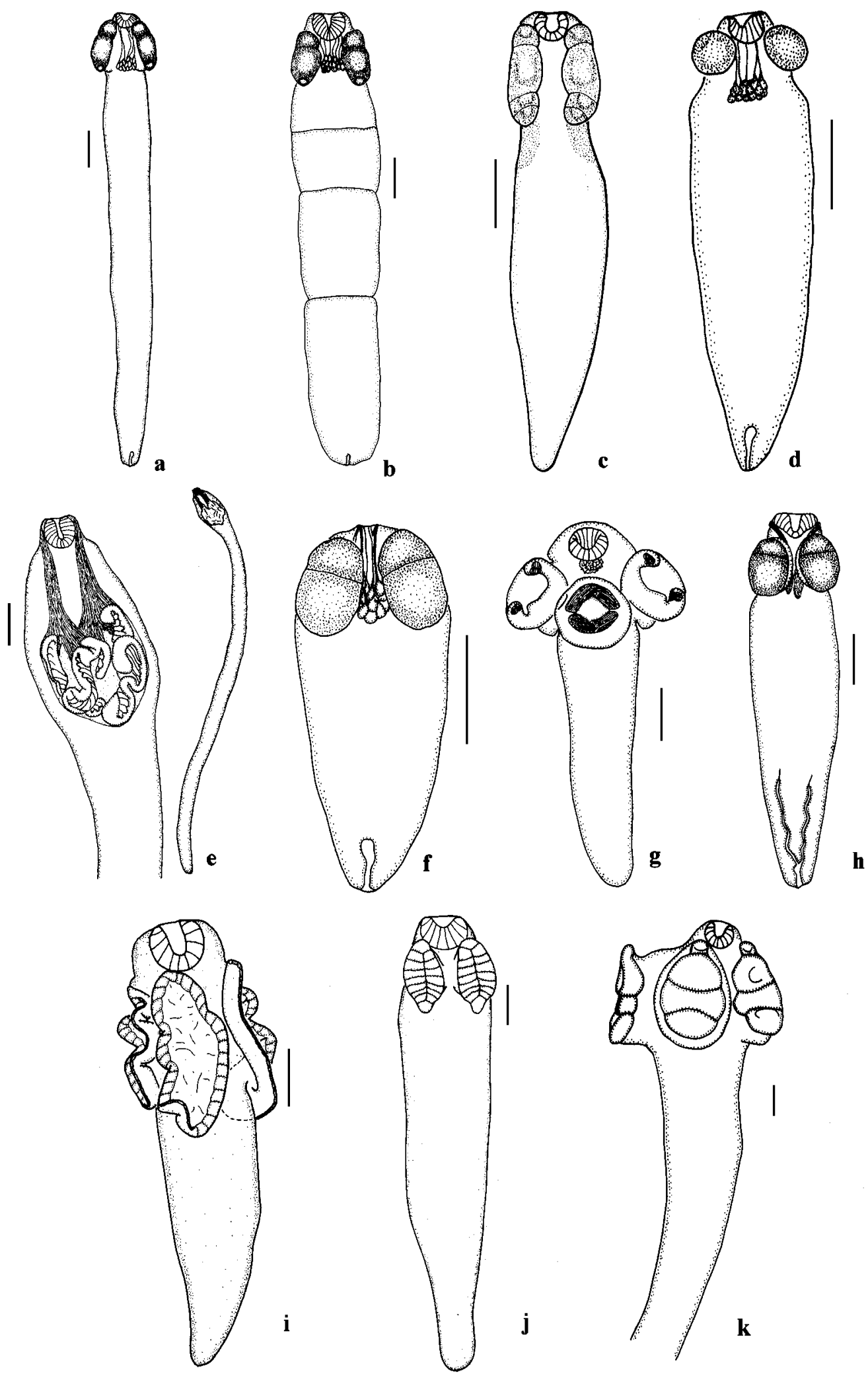

Fig. 1. Putative tetraphyllidean 'types' as determined by light microscopy. a - Type 1 metacestode; $\mathbf{b}$ - Type 2 metacestode; c-Type 3 metacestode; d - Type 4 metacestode; e - Type 5 metacestode; $\mathbf{f}$ - Type 6 metacestode; $\mathbf{g}$ - Type 7 metacestode; $\mathbf{h}$ - Type 8 metacestode; $\mathbf{i}$ - Type 9 metacestode; $\mathbf{j}$ - Type 10 metacestode; $\mathbf{k}$ - Type 11 metacestode. Scale bars $=100 \mu \mathrm{m}$. 
Table 1. Host/parasite list of tetraphyllidean metacestodes from Heron Island.

\begin{tabular}{|c|c|c|}
\hline Type & Host family & Host species \\
\hline 1 & $\begin{array}{l}\text { Labridae } \\
\text { Serranidae }\end{array}$ & $\begin{array}{l}\text { Anampses caeruleopunctatus Rüppell, A. geographicus Valenciennes, Coris } \\
\text { batuensis (Bleeker), Hemigymnus fasciatus (Bloch), Thalassoma hardwicke } \\
\text { (Bennett), T. lunare (Linnaeus), T. lutescens (Lay et Bennett) } \\
\text { Plectropomus maculatus (Bloch) }\end{array}$ \\
\hline 2 & $\begin{array}{l}\text { Gobiidae } \\
\text { Labridae } \\
\text { Lutjanidae }\end{array}$ & $\begin{array}{l}\text { Bathygobius fuscus (Rüppell) } \\
\text { Cheilinus chlorourus (Bloch), Hemigymnus melapterus (Bloch), Thalassoma } \\
\text { hardwicke, T. lunare } \\
\text { Lutjanus fulviflamma (Forsskål) }\end{array}$ \\
\hline 3 & Gobiidae & Valenciennea longipinnis (Lay et Bennett) \\
\hline 4 & $\begin{array}{l}\text { Batrachoididae } \\
\text { Caesionidae } \\
\text { Carangidae } \\
\text { Gerreidae } \\
\text { Gobiidae } \\
\text { Labridae } \\
\text { Lethrinidae } \\
\text { Lutjanidae } \\
\text { Pinguipedidae } \\
\text { Scombridae } \\
\text { Serranidae } \\
\text { Sparidae }\end{array}$ & $\begin{array}{l}\text { Halophryne diamensis (LeSueur) } \\
\text { Caesio cuning (Bloch), Pterocaesio marri Schultz } \\
\text { Scomberoides lysan (Forsskål), Trachinotus blochii (Lacepède) } \\
\text { Gerres oyena (Forsskål) } \\
\text { Amblygobius phalaena (Valenciennes), Asterropteryx semipunctatus Rüppell, } \\
\text { Bathygobius cocosensis (Bleeker), B. fuscus, Valenciennea longipinnis } \\
\text { Anampses neoguinaicus Bleeker, Cheilinus chlorourus, Choerodon venustus } \\
\text { (De Vis), Coris batuensis, Halichoeres marginatus Rüppell, H. trimaculatus } \\
\text { (Quoy et Gaimard), Hemigymnus fasciatus, H. melapterus, Stethojulis } \\
\text { strigiventer (Bennett), Thalassoma hardwicke, T. lunare } \\
\text { Lethrinus atkinsoni Seale } \\
\text { Lutjanus carponotatus (Richardson), L. fulviflamma } \\
\text { Parapercis cylindrica (Bloch) } \\
\text { Scomberomorus commerson (Lacepède) } \\
\text { Cephalopholis boenak (Bloch), C. cyanostigma (Valenciennes) } \\
\text { Acanthopagrus australis (Günther) }\end{array}$ \\
\hline 5 & $\begin{array}{l}\text { Batrachoididae } \\
\text { Echeneidae } \\
\text { Gerreidae } \\
\text { Gobiidae } \\
\text { Labridae } \\
\text { Lutjanidae } \\
\text { Pinguipedidae }\end{array}$ & $\begin{array}{l}\text { Halophryne diamensis } \\
\text { Echeneis naucrates Linnaeus } \\
\text { Gerres oyena } \\
\text { Amblygobius phalaena, Bathygobius fuscus, Valenciennea longipinnis } \\
\text { Cheilinus chlorourus, Choerodon venustus, Halichoeres trimaculatus, } \\
\text { Hemigymnus melapterus, Thalassoma hardwicke, T. lunare } \\
\text { Lutjanus fulviflamma } \\
\text { Parapercis cylindrica }\end{array}$ \\
\hline 6 & $\begin{array}{l}\text { Caesionidae } \\
\text { Labridae } \\
\text { Serranidae }\end{array}$ & $\begin{array}{l}\text { Pterocaesio marri } \\
\text { Thalassoma lunare } \\
\text { Cephalopholis boenak }\end{array}$ \\
\hline 7 & $\begin{array}{l}\text { Labridae } \\
\text { Lutjanidae }\end{array}$ & $\begin{array}{l}\text { Thalassoma hardwicke } \\
\text { Lutjanus carponotatus }\end{array}$ \\
\hline 8 & $\begin{array}{l}\text { Caesionidae } \\
\text { Carangidae } \\
\text { Labridae } \\
\text { Lethrinidae } \\
\text { Pomacentridae } \\
\text { Scombridae } \\
\text { Serranidae } \\
\end{array}$ & $\begin{array}{l}\text { Caesio cuning, Pterocaesio marri } \\
\text { Trachinotus bailloni (Lacepède), T. blochii } \\
\text { Thalassoma hardwicke, T. lunare } \\
\text { Lethrinus atkinsoni } \\
\text { Abudefduf bengalensis (Bloch), A. whitleyi Allen et Robertson, } \\
\text { Acanthochromis polyacanthus (Bleeker) } \\
\text { Scomberomorus commerson } \\
\text { Cromileptes altivelis (Valenciennes) }\end{array}$ \\
\hline 9 & Labridae & Halichoeres trimaculatus \\
\hline 10 & Labridae & Halichoeres trimaculatus, Thalassoma lunare \\
\hline 11 & $\begin{array}{l}\text { Labridae } \\
\text { Lutjanidae }\end{array}$ & $\begin{array}{l}\text { Thalassoma lunare } \\
\text { Lutjanus adetii (Castelnau) }\end{array}$ \\
\hline
\end{tabular}

onchobothriid by the development of hooks between the $1^{\text {st }}$ and $2^{\text {nd }}$ loculi. Hook development between the anterior two loculi is consistent with observations by Hamilton and Byram (1974) on scolex developmental processes in a species of Acanthobothrium van Beneden, 1849 which they also cultivated in vitro. This observation supports the hypothesis of Caira and
Ruhnke (1991) that, in respect to matching larval morphology with adult morphology, the number of loculi in the metacestode will equal the number of posthook loculi in the adult, plus one (to include the anterior muscular pad). There are two post-hook loculi in the cultivated scolex of Type 1, suggesting that this type belongs to either Uncibilocularis Southwell, 1925 or 

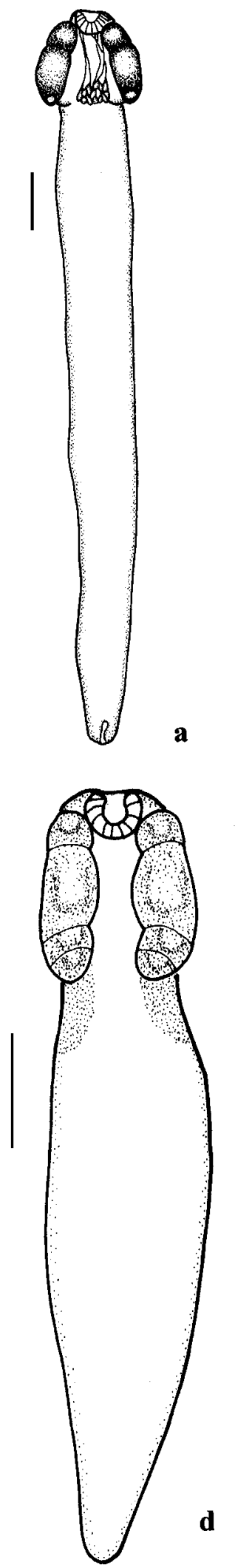

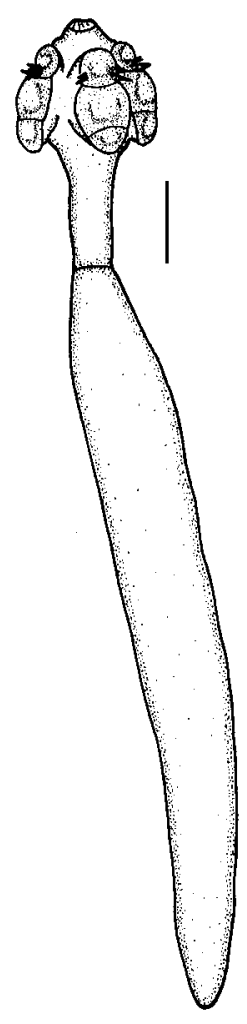

b

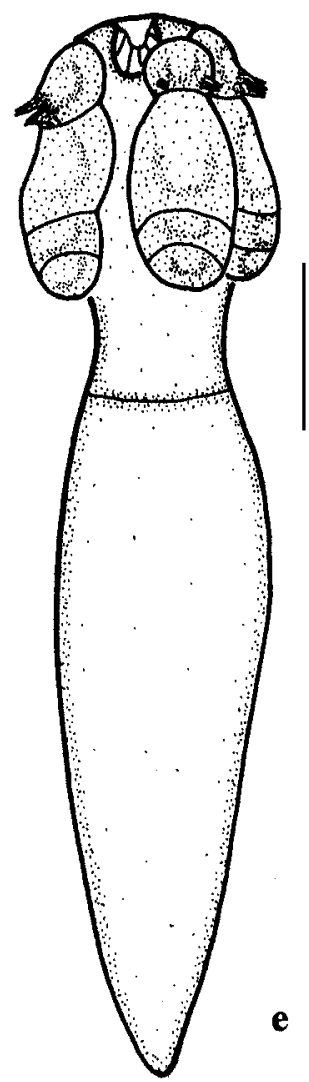

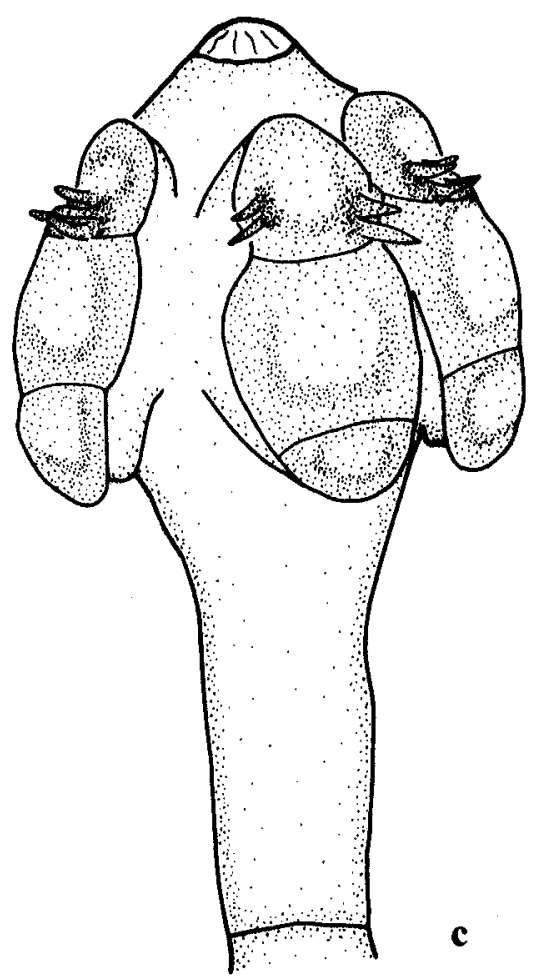

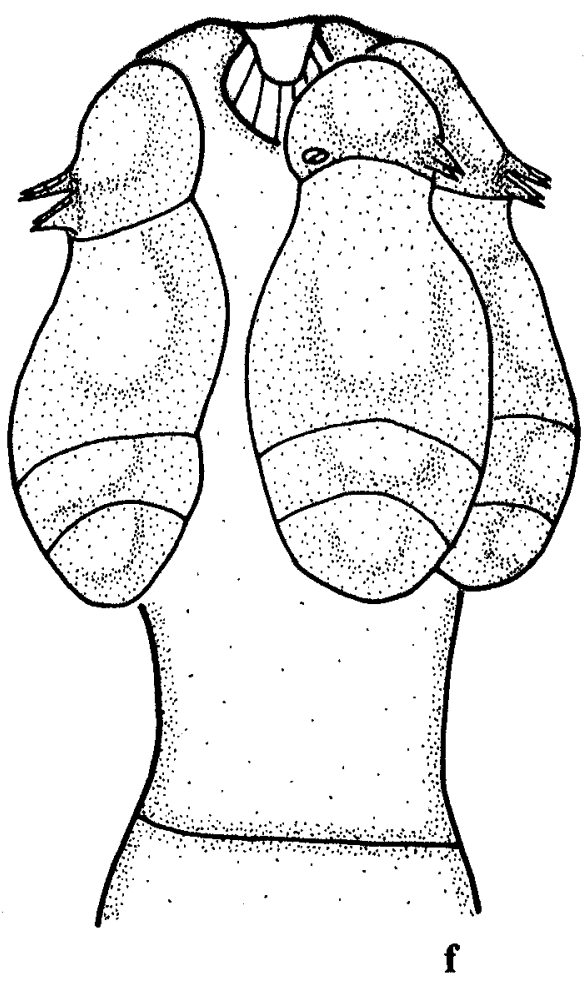

Fig. 2. Developmental morphology of onchobothriid metacestodes. a-morphology of an uncultivated Type 1 metacestode; b-Type 1 metacestode cultivated in vitro for 96 hours; c-scolex of a Type 1 metacestode cultivated in vitro for 72 hours; d-morphology of an uncultivated Type 3 metacestode; e - Type 3 metacestode cultivated in vitro for 72 hours; f - scolex of a Type 3 metacestode cultivated in vitro for 48 hours. Scale bars $=100 \mu \mathrm{m}$. 
Table 2. Measurements of tetraphyllidean metacestode 'types' and putative identity. Measurements in micrometres.

\begin{tabular}{|c|c|c|c|c|c|c|c|}
\hline Type & $\begin{array}{c}\text { Number } \\
\text { examined }\end{array}$ & Body length $\times$ width & $\begin{array}{l}\text { Apical sucker } \\
\text { length } \times \text { width }\end{array}$ & $\begin{array}{l}\text { Bothridial length } \times \\
\text { width }\end{array}$ & $\begin{array}{l}\text { Loculi number } \\
\text { per bothridium }\end{array}$ & Putative identity & $\begin{array}{l}\text { QM Accession } \\
\text { numbers }\end{array}$ \\
\hline 1 & 20 & $\begin{array}{l}1277(539-1825) \\
\times 146(111-199)\end{array}$ & $\begin{array}{r}47(39-56) \\
\times 56(42-69)\end{array}$ & $\begin{array}{l}128(94-170) \\
\times 57(38-86)\end{array}$ & 3 & Uncibilocularis & $\begin{array}{l}\text { G } 217943- \\
\text { G } 217947\end{array}$ \\
\hline 2 & 10 & $\begin{array}{l}1077(673-1507) \\
\times 205(172-236)\end{array}$ & $\begin{array}{r}73(61-80) \\
\times 86(69-94)\end{array}$ & $\begin{array}{l}131(121-145) \\
\times 70(55-84)\end{array}$ & 3 & Uncibilocularis & $\begin{array}{l}\text { G } 217948- \\
\text { G } 217952\end{array}$ \\
\hline 3 & 10 & $\begin{array}{r}619(590-692) \\
\times 128(103-151)\end{array}$ & $\begin{array}{l}41(39-42) \\
\times 49(45-51)\end{array}$ & $\begin{array}{l}134(118-147) \\
\times 49(42-55)\end{array}$ & 4 & $\begin{array}{l}\text { Acanthobothrium or } \\
\text { Calliobothrium }\end{array}$ & $\begin{array}{l}\text { G } 217953- \\
\text { G } 217957\end{array}$ \\
\hline 4 & 40 & $\begin{array}{r}657(439-1240) \\
\times 165(100-235)\end{array}$ & $\begin{array}{r}41(31-55) \\
\times 52(41-71)\end{array}$ & $\begin{array}{r}65(51-90) \\
\times 61(45-90)\end{array}$ & 1 & Anthobothrium & $\begin{array}{l}\text { G } 217958- \\
\text { G } 217962\end{array}$ \\
\hline 5 & 21 & $\begin{array}{l}3506(1440-8800) \\
\times 363(257-481)\end{array}$ & $\begin{array}{r}109(71-167) \\
\times 122(77-160)\end{array}$ & $\begin{array}{l}\text { Inverted, contained } \\
\text { in pouches }\end{array}$ & $48 / 74^{*}$ & $\begin{array}{c}\text { Rhinebothrium, Caulobothrium or } \\
\text { Rhabdotobothrium }\end{array}$ & $\begin{array}{l}\text { G } 217963- \\
\text { G } 217967\end{array}$ \\
\hline 6 & 9 & $\begin{array}{l}305(195-409) \\
\times 111(59-161)\end{array}$ & Absent & $\begin{array}{c}87(48-131) \\
\times 97(53-138)\end{array}$ & 2 & Undetermined & $\begin{array}{l}\text { G } 217968- \\
\text { G } 217972\end{array}$ \\
\hline 7 & 3 & $\begin{array}{l}1251(724-1658) \\
\times 286(177-344)\end{array}$ & $\begin{aligned} & 64(51-84) \\
\times & 92(80-100)\end{aligned}$ & $\begin{array}{r}193(148-225) \\
\times 199(148-225)\end{array}$ & 1 & Undetermined & $\begin{array}{l}\text { G } 217973- \\
\text { G } 217975\end{array}$ \\
\hline 8 & 20 & $\begin{array}{r}890(534-1835) \\
\times 161(113-225)\end{array}$ & $\begin{aligned} & 58(39-97) \\
\times & 100(80-142)\end{aligned}$ & $\begin{array}{l}112(94-138) \\
\times 72(58-90)\end{array}$ & 2 & Undetermined & $\begin{array}{l}\text { G } 217976- \\
\text { G } 217980\end{array}$ \\
\hline 9 & 1 & $799 \times 177$ & $93 \times 100$ & $\begin{array}{l}\text { Unable to be } \\
\text { determined }\end{array}$ & $\begin{array}{l}\text { Leaf-like, with a } \\
\text { row of marginal } \\
\text { loculi }\end{array}$ & $\begin{array}{l}\text { Phyllobothrium or } \\
\text { Clydonobothrium }\end{array}$ & G 217981 \\
\hline 10 & 8 & $\begin{array}{r}857(651-1464) \\
\times 243(142-406)\end{array}$ & $\begin{aligned} & 100(71-219) \\
\times & 122(77-206)\end{aligned}$ & $\begin{array}{l}\text { Variable, depending } \\
\text { on loculi number }\end{array}$ & $20(12-46)$ & $\begin{array}{c}\text { Rhinebothrium, Caulobothrium or } \\
\text { Rhabdotobothrium } \\
\text { Acanthobothrium }\end{array}$ & $\begin{array}{l}\text { G } 217982- \\
\text { G } 217986\end{array}$ \\
\hline 11 & 3 & $\begin{array}{c}2209(1967-2451) \\
\times 348(303-393)\end{array}$ & $77 \times 130$ & $\begin{array}{c}341(335-348) \\
\times 209(193-226)\end{array}$ & 4 & $\begin{array}{c}\text { Acanthobothroides, } \\
\text { Calliobothrium or } \\
\text { Onchobothrium }\end{array}$ & $\begin{array}{l}\text { G } 217987- \\
\text { G } 217988\end{array}$ \\
\hline
\end{tabular}

* In vitro cultivation revealed the presence of two distinct forms within this type; one with 48 loculi, the other with 74 loculi. 

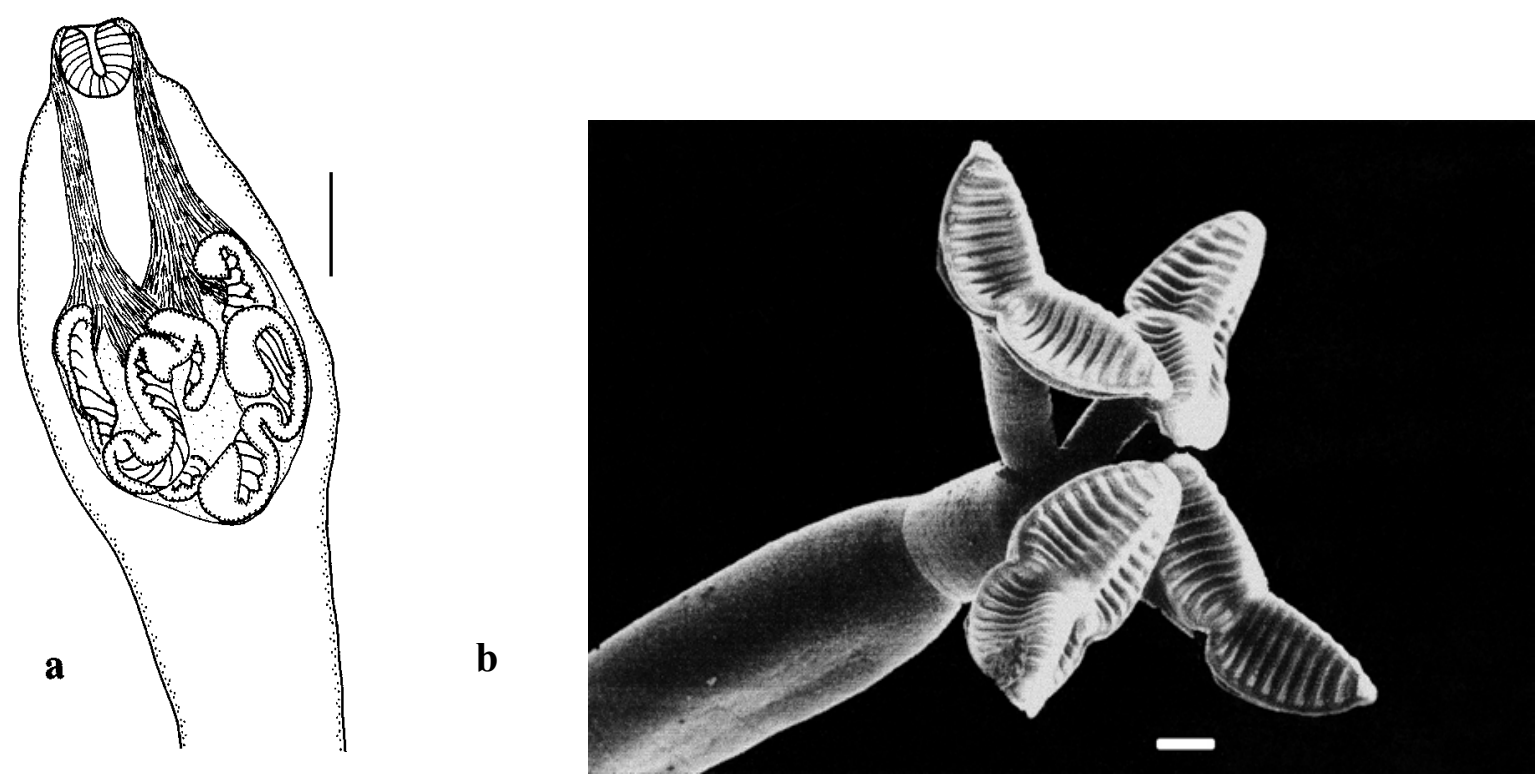

Fig. 3. Morphology of Type 5 metacestodes. a - scolex morphology of an uncultivated Type 5 metacestode; b - SEM micrograph of the scolex of a Type 5 metacestode cultivated for 72 hours. Scale bars $=100 \mu \mathrm{m}$.

Megalonchos Baer et Euzet, 1962. The hook morphology, one pair of symmetrical forked hooks per bothridium with unequal prongs, corresponds to that of Uncibilocularis. Metacestode Type 2 is very similar to Type 1 in morphology, so may represent a separate species of Uncibilocularis.

Metacestode Type 3 was also identified as an onchobothriid. The scolex morphology corresponds to Acanthobothrium and Calliobothrium van Beneden, 1850 , but the hook development was not sufficiently advanced to distinguish between these two genera. If there is one pair of forked hooks per bothridium, then the metacestodes belong to Acanthobothrium. If there are two pairs of single hooks, then they belong to Calliobothrium.

Metacestode Type 4 did not develop hooks after three weeks of cultivation suggesting that these metacestodes belong to the Phyllobothriidae Braun, 1900. In culture, the bothridia retained a simple edge and became slightly pedunculate, suggesting that these metacestodes represent members of Anthobothrium van Beneden, 1850.

Evagination of the bothridia of Metacestode Type 5 revealed four bothridia divided into numerous loculi by a single longitudinal septum and several transverse septa. This character accords well with the metacestodes belonging to the subfamily Rhinebothriinae Euzet, 1953. These metacestodes may belong to any of the genera Rhinebothrium Linton, 1889, Caulobothrium Baer, 1948 or Rhabdotobothrium Euzet, 1953. Knowledge of adult gonadal arrangement is needed to distinguish between these genera.
The pattern of development observed in cultivated onchobothriid metacestodes (Type 1, 2, and 3) corresponds with that recorded by Hamilton and Byram (1974) for a species of Acanthobothrium and by Caira and Ruhnke (1991) for Calliobothrium verticillatum Rudolphi, 1829. These patterns include the degeneration of the apical sucker (the apical sucker is eventually lost in the adult scolex) and the development of hooks between the $1^{\text {st }}$ and $2^{\text {nd }}$ loculi of the metacestodes. Hamilton and Byram (1974) and Caira and Ruhnke (1991) reported the development of accessory suckers in the anterior muscular pads of their respective species, which was not observed in the species cultivated in this study.

Our in vitro studies support the theory of Avdeeva and Avdeeva (1980) and Caira and Ruhnke (1991) that all of the bothridial loculi are present early in the development of the onchobothriid metacestode and are not added sequentially as the worm matures, as was suggested by Curtis (1911). It is not known if this is also the case for phyllobothriid worms.

The cultivation of metacestodes in vitro is a technique with great potential. It enabled better resolution of metacestode identification, revealed the presence of cryptic species and also provided further support for theories on onchobothriid scolex development. In vitro techniques may be extremely useful in tracing developmental patterns of reproductive structures, as well as hook and scolex differentiation of tetraphyllideans, due to the difficulty of maintaining the definitive hosts in captivity. 


\section{REFERENCES}

AVDEEVA N.V., AVDEEVA V.V. 1980: Features of the morphogenesis of the organs of attachment in some plerocercoids from the composite genus "Scolex" (Tetraphyllidae) and the problems attached to their identification. Parazitologiya (Leningrad) 14: 242-250. (In Russian.)

CAIRA J.N., RUHNKE T.R. 1991: A comparison of scolex morphology between the plerocercoid and the adult of Calliobothrium verticillatum (Tetraphyllidea: Onchobothriidae). Can. J. Zool. 69: 1484-1488.

CARVAJAL J., BARROS C., SANTANDER G. 1982: In vitro culture of Rhodobothrium mesodesmatum (Cestoda: Tetraphyllidea), parasite of a Chilean clam. Proc. Helminthol. Soc. Wash. 49: 226-230.

CURTIS W.C. 1911: The life history of the Scolex polymorphus of the Woods Hole region. J. Morphol. 22: 819853.

DICK T.A., CHOUDHURY A. 1995: Cestoidea (Phylum Platyhelminthes). In: P.T.K. Woo (Ed.), Fish Diseases and Disorders. Vol. 1. University Press, Cambridge, pp. 391414.
HAMILTON K.A., BYRAM J.E. 1974: Tapeworm development: the effects of urea on a larval tetraphyllidean. J. Parasitol. 60: 20-28.

LESTER R.J.G., SEWELL K.B. 1989: Checklist of parasites from Heron Island, Great Barrier Reef. Aust. J. Zool. 37: 101-128.

RUDOLPHI C.A. 1819: Entozoorum synopsis cui accedunt mantissa duplex et indices locupletissimi. Berolini, pp. 128-129.

RUSSELL B.C. 1993: Fishes. In: P. Mather and I. Bennett (Eds.), A Coral Reef Handbook: a Guide to the Geology, Flora and Fauna of The Great Barrier Reef. Third Edition. Surey Beatty and Sons Pty Ltd., Chipping Norton, pp. 185-197.

STUNKARD H.W. 1977: Studies on tetraphyllidean and tetrarhynchidean metacestodes from squids taken on the New England Coast. Biol. Bull. (Woods Hole) 153: $387-$ 412.

WARDLE R.A., McLEOD J.A. 1952: The Zoology of Tapeworms. Minnesota Press, Minneapolis, pp. 227-268. 